\title{
A CENTURY OF NU-MUHAMMADIYAH IN INDONESIA: THE FAILURE OF ISLAMIC MODERNISM?
}

\author{
Moeflich Hasbullah \\ Faculty of Adab and Humaniora \\ State Islamic University Sunan Gunung Djati \\ Jl. A.H. Nasution 105 Bandung 40614, Indonesia \\ moeflich@uinsgd.ac.id,phone: +62-811901165
}

\begin{abstract}
Islamic modernism represented by Muhammadiyah and Persatuan Islam and Islamic traditionalism symbolized by Nahdlatul Ulama have lasted a century old in Indonesian history (1912-2014). The unavoidable tensions and conflicts between these two contrast Islamic movements occurred in various fields. The modernist has been trying to promote their modern views and to eradicate tradition. On the contrary, the traditionalist has been working hard to maintain their Islamic tradition and fight for the modernist mission in disseminating their ideas. To some extent, the modernist is quite successful, however by comparative study methods applied in this article to see the result of these two Islamic streams, I argue that in common Islamic modernism has failed to weaken and to eradicate tradition as it was firstly introduced by their initiators over a century ago. The modernist is only successful in its attempt to build its own empire of modernism but without vanishing tradition. Rather than weakening, let alone disappearing, what has been occuring shows the opposite result. Islamic traditionalism even grows larger than modernist group and develops more dynamic in various fields. More than that, Islamic neo-traditionalism has emerged as its new variant, an intellectual movement that found a new land on the problems of modern spiritual drought.
\end{abstract}

Keywords: Islam Indonesia; traditionalism; modernism; Islamic renewal, failure.

"The triumph of Islam was never meant that it managed to scrape out the ideas of the pre-Islamic roots. On the contrary, everywhere there is something of the old who still lived... This is also seen in the Indonesian people. 
Certain ways of thinking that for Indonesian people In the pre-Islamic era is special, seems so fundamental, so that the prolonged contact with Islam did not succeed to change the ways of thinking, and in many areas, the indigenous cultures are still widely survived."

(G.W.J. Drewes in Simuh 2003: 48)

\section{INTRODUCTION}

The aim of this article wants to answer the question, has traditional Muslim culture in Indonesia disappeared after a century of the existence of Islamic modernism as represented by Muhammadiyah and other smaller organizations?' To what extent Islamic modernism is successful and to what level traditional culture has vanished? So far, there is no academic account analyzing this issue, whereas this contest is challenging to think about and discovering the answer. Many Muslim traditional speakers are still quite worry about the disappearance of Islamic tradition since the emergence of reform movements in Muslim societies a century ago. For that reason, the conflict between the two groups is continuing until today.

Since the appearance of Islamic modernism and traditionalism in the Muslim world, Indonesia is perhaps the most interesting field to see the contest between the two stream. Among Muslim nations, only in Indonesia traditionalism manifests itself into the resistant movement against the Islamic modernism. Tension and conflict of both sides have lasted a century old, from the beginning of the 20th century up to now. It is interesting that the conclusions that could be drawn from such a long feud, Islamic modernism has seemingly failed to eradicate traditions as it was firstly introduced by their modernist initiators over a century ago primarily Muhammadiyah.

Rather than disappear, this article argues, what has been occuring surprisingly shows the opposite result. A lot of facts will be shown in this article to prove that the main goal of modernism, to many extents, have failed and religious traditionalism amongst Indonesian Muslims is not just survived but it even gets more new followers in line with fast social change produced by the process modernization. Islamic traditionalism as represented by Nahdhatul Ulama (NU), instead of reducing, even grows larger than modernist group. It also develops more dynamic in its vast terrain: traditional religious practices and thought, political movement and its influences to the mass. More than that, Islamic neo-traditionalism has been emerging as its new variant, an intellectual movement that found a new land on the problems of modern spiritual drought. 


\section{MATERIALS AND METHODS}

This article will develop the argument by using the methods of comparative analyses, a research technique originally introduced by Charles Ragin. ${ }^{1}$ (1987). This is the research methodology in the social sciences that compares two or more socio-cultural phenomena across different countries or cultures. The contrasting data of recent development of Islamic traditionalism and modernism in Indonesia will be analyzed to show the different result gained by these two Islamic streams in their efforts to spread and maintain their own religious ideologies for one hundred years.

The materials used in this research are doctrines and achievements of the two organizations and their supporters. In the pole of Islamic tradition, there are historical and cultural facts, educational institutions (pesantren) including the forms of traditional religious consciousness that have been shaped for centuries. In the opposite wing, what Islamic modernism has built to promote modern ideas and thought as applied in economic movements and educational institutions of Muhammadiyah and Persatuan Islam in modernizing Indonesian Muslims. Examining this long ideological contest that has been occurring in a century is an interesting research to evaluate the current phenomena of Indonesian modern landscape to recognize what have been obtained by the two different religious orientations, why some are successful and some are failed and what the meaning of them all.

\section{RESULT AND DISCUSSION}

\section{A. Islamic modernism}

In the modern period of Islamic world, the conflict of thought firstly emerged as an internal dynamics of Muslims facing the formative religious doctrines (seeking truth), while in modern times it comes up in response to the backwardness of Muslim from the West (giving answers). "Giving answers" appears in two forms of movements: First, inward-looking criticism, and the second, reactive movement that is oriented to outer issues (outward looking).

Inward looking criticism movement is an effort to find the source of the internal Islamic problems by pointing index finger againts Muslim rigidity, backwardness and stagnation. Traditionalism and heterodoxy are to be blamed. This movement states that the practices of superstition, heresy, and the doctrine of sufism in the Islamic world are responsible for the Muslim backwardness. Allegedly said, due to the teachings of sufism, the ummah immersed in the individual religious satisfaction, spiritual

\footnotetext{
${ }^{1}$ Charles C. Ragin, The Comparative Method: Moving Beyond Qualitative and Quantitative Strategies (California: University of California Press, 1989).
} 
ecstasy and escapist joy. Traditionalism is deemed to be the opposite of progress and modern productivity. For the advancement of Islam, the ummah should leave such traditional orientation. Meanwhile, reactive movement called for progress by looking at the modern Western world as a model and stimulus for change. Islamic renewal by imitating what has been achieved by modern Western civilization is its strategy.

Inward-looking criticism movement is associated to Muhammad bin 'Abdul Wahhāb (1703-1778) in Saudi Arabia, a prolific scholar who was encouraged by the ideas of Ibn Taimiyyah. Abdul Wahhāb saw the body of the Muslim ummah as the source of the problem. The Muslim underdevelopment and backwardness took place because they have been far away from the purely religious teachings as found in the authentic sources, the Quran and hadith. Of the diagnosis, Abdul Wahhāb pioneered the movement of Islamic purification of religious practices that deviate from the straight guidance of monotheism. For Wahhāb, in the situation of power decline of the $18^{\text {th }}$ century Ottoman Empire thanks to many dynasties rebellion, Muslim community itself is being weakened by passive religious behaviors, mysticism and rampant superstition such as taqlid, tawassul, ziyārah, the rise of sufi teachings, tariqah practices and respect for the dead saints (waliyulläh). All these have been the cause of the fatalistic and escaphist attitudes among the people. When Wahhāb thoughts get lots of followers and found fertile ground of backwardness, especially in the Arabian Peninsula, his teachings evolved into a movement known as Wahhābism that is radical and uncompromising to eradicate what he regarded as "the effects of non-Islam." 2 In the $20^{\text {th }}$ century, Wahhāb followers get authority support after the rising power of 'Abd al-'Aziz ibn $\mathrm{Sa}^{\text {'ud }}$ who became the king of Saudi Arabia in 1924. Ibn Sa'ud kingdom that embraced Wahhābi teaching, then immediately becomes a political vehicle that facilitates the spread of this ideology to the Muslim communities outside the Arab such as Libya, Sudan, India and Indonesia. ${ }^{3}$

\footnotetext{
${ }^{2}$ The Wahhābi bans all forms of religious reverence. To prevent the development of attitudes among the people of the cult, the Wahhābis destroyed what it thinks could bring in idolatry. In 1802, they attacked Karbala because there was a grave of Hussein bin 'Ali bin Abī Thālib that the Shi'ites were very adoring, destroying the domes that exist in the grave, and leveled with the ground, destroying the ornaments on the grave of the Prophet, damaging the cover kiswah of the Ka'bah even destroy houses relics of the Prophet Muhammad Peace be upon him. See Ester Peskes and C. Holes, "Wahhābiyya," The Encyclopedia of Islam, ed. P. J. Bearman, Th. Bianquis, C. E. Bosworth, E. van Donzel and W. P. Heinrichs (Leiden: Brill, 2002), 11: 39-47.

${ }^{3}$ In Indonesia, the influence of Wahhābi entered the Padri group in Sumatra that clashed with the indigenous people. See Karel A. Steenbrink, Beberapa Aspek Tentang Islam di Indonesia Abad Ke-19 (Jakarta: Bulan Bintang, 1984); Taufik Abdullah (ed.), Sejarah dan Masyarakat: Lintasan Historis Islam di Indonesia (Jakarta: Pustaka Firdaus, 1987), 104-127. While Islamic organizations associated with Wahhābī doctrine are Muhammadiyah and Persatuan Islam whose mission is to clean up the Muslim traditional practices such as shrik, bid'ah, khurāfah and takhayyul. See Delia Noer, Gerakan Modern Islam 1900-1042 (Jakarta: Bulan Bintang, 1985). In rural and rurban communities of Java until the 1970s, the traditionalist supporters called the reformer school of thought as a "new religion" because it proscribes religious traditions that have been rooted in the realm of consciousness and social system.
} 
On the other hand, different response appears in the form of modernization of the $19^{\text {th }}$ century that saw the West as a stimulus to the progress of Islamic reform movement. The movement is concentrated in oecumene areas like Egypt as the center of Islamic civilization. Here the figures such as Muhammad 'Ali Pāshā (1765-1849) and al-Ṭahtậīi (1801$1873)$ are in direct contact with the occupation of Napoleon Bonaparte in Egypt during the reign of Ottoman Turkey. Directly contacted with the progress of the West, Ali Pasha and Tahtāwi promoted delivery program of Muslim students to Europe and initiated books translation into Arabic. ${ }^{4}$ The peak of this modernization movement is associated to the three most prominent figures namely Jamāl al-Dīn al-Afghānī (1839-1897), Muhammad 'Abduh (1845-1905) and Muhammad Rashīd Riḍā (18651935). Al-Afghānī, a Ḥanafi follower and political activist from Afghanistan carried Pan-Islamism movement that attempts to unite the Muslim world in the spirit of leaving setbacks and encouraging progress. With 'Abduh, al-Afghāni published a magazine Al-'Urwah al-Wuthqā to deploy his modern thoughts. ${ }^{5}$

In addition, he wrote several books whose content to resuscitate the Muslims from their backwardness compared to the Western world. ${ }^{6}$ Afghāni's ideas then "get the ideological and theological framework" especially from his disciples, "Abduh and Rida". "Abduh's modernism declared that Muslim setback is caused by the stagnation of the attitude of the people of old-fashioned thinking and rigidity that impede progress. Therefore, it is important to abandon dogmatic attitudes and develop the spirit of thinking to reopen the doors of ijtihäd. He said that modern rationalism is in line with the command of the usage of mind in Islam to develop science. From the womb of Islamic modernism, than there emerges other figures who continue his movement such as Sayyid Ahmmad Khān (d. 1898), Amir 'Ali (d. 1928), Muhammad Iqbal (1938), Abul Kalam Azad (1958) and others.

\footnotetext{
${ }^{4}$ Harun Nasution, Pembaruan dalam Islam: Sejarah Pemikiran dan Gerakan (Jakarta: Bulan Bintang, 1992), 34-50.

${ }^{5}$ The magazine is famous in Indonesia in beginning of the 20th century as one of the inspiration of modern Islamic movements. Al- 'Urwah al-Wuthqa' renewal and other magazines such as al-Manār and the books of the modernist view, accessible to the people of Islam in the Archipelago through the activities of the Hajj in Mecca, Medina and Cairo also later, after Hajj, the Islamic movement inspired them to establish modernism in Indonesia. See Noer, Gerakan Modern Islam; Martin van Bruinessen, "Mencari Ilmu dan Pahala di Tanah Suci: Orang Nusantara Naik Haji," Ulumul Qur'an, 2: 5 (1990): 42- 49. The impact, in the Archipelago itself that carries the rising magazines/journal renewal as al-Imām (1906-1908) published in Singapore, al-Munīr in Padang (19111916), Bintang Islam (1923) and Bendera Islam (1924) issued respectively by Sarekat Islam and Muhammadiyah, Pembela Islam and Soal-Jawab by Persatuan Islam, etc. A discussion of the early Islamic publications of the 20th century, see Azyumardi Azra, Jaringan Global dan Lokal Islam Nusantara (Bandung: Mizan, 2002), 181-202; Jajat Burhanuddin, "The Fragmentation of Religious Authority: Islamic Print Media in Early $20^{\text {th }}$ Century Indonesia," Studia Islamika: Indonesian Journal for Islamic Studies, 11: 1 (2004): 23-62.

${ }^{6}$ For instance, al-Afghānì's works such as Bāb mā Ya'ūlu ilayh Amr al-Muslimīn, Risālah fì al-Radd 'alā alMasīhiyyīn, Diyā' al-Khafiqayn, Haqīqat al-Insān wa Haqīqat al-Watān, etc.

${ }_{7}$ Fachry Ali and Bahtiar Effendy, Merambah Jalan Baru Islam: Rekonstruksi Pemikiran Islam Indonesia Masa Orde Baru (Bandung: Mizan, 1986), 63.
} 
From above description, it appears that from "the movement of selfcriticism" that is purificative to "eye-opening movement" of Islamic modernism of the 19th century that is imitative, both call for moving forward by fighting tradition that has trapped Muslim world in decline. Interestingly, in the vigorous effort to eliminate the role of tradition, on the other hand, there furtively emerges an active resistance of the Islamic traditionalism.

\section{B. The Resistance of Traditionalism}

The widespread movement of self-criticism promoted by Muhammad ibn 'Abd al-Wahhāb until gaining the support of the royal authority of Ibn $\mathrm{Sa}^{\text {'ud }}$ in the $20^{\text {th }}$ century, in its development, produces an unexpected backlash. The spreading influence of the modernist reform movement from its headquarters in Cairo to Mecca and to Southeast Asia, on the other hand, has provided for a fertile ground of Islamic traditionalism. In other words, the very confident renewal movement has provided fresh blood for the affirmation of the identity of traditionalism. This is because the inseparable "vested interest" and political identity that accompanied the reformism. When the modernist idea evolved into a group-oriented movement, what happend later is no longer modernization and an earnest appeal in progress, but socialization and affirmation of group identity. This tendency is always inevitable in any social groups and religious organizations elsewhere, including in Indonesia. The presence of aggressive reformism which is uproarious, instead of providing awareness and inspiring progress, what seen by its opponents is a carnival of identity, parade of attack that expressed through clamorous "sprinkling of curse." Instead of awakening, what is perceived is the noise of disturbance.

Back to purity, in this connection, does not necessarily mean an invitation to explore the essence of Islam. But rather a strategy of political discourse (politics) to show a clear boundary between the discourse of the mistake of his opponents and his own people that is true. Therefore, the final result of the movement back to the purity is not the invention of the essence of Islamic teachings in its relevance to today's problem, but merely a rejection of other type of fiqh by studding "curse."

\footnotetext{
${ }^{8}$ The same was done by Islamic traditionalism: "The idea of indigenization and maintenance of the $A h l a l-$ Sunnah wal Jama' 'ah tradition developed among NU, does not have to mean a willingness to find a theology that is more relevant and empowering the local community context. It is more driven by an interest in maintaining privilege kiai through the linkage between mastery of tradition and authority. Thus, the will to preserve the past is more a means to conserve power. So the end result of this project is not the empowerment of people, but trapped in an attempt to politicize the tradition by perpetuating the conflict with the modernist discourse." See Yudi Latif, Masa Lalu Yang Membunuh Masa Depan: Krisis Agama, Pengetahuan dan Kekuasaan dalam Kebudayaan Teknokratis (Bandung: Mizan, 1999), 21.
} 
Psychologically, a stronghold of offensive attitudes will always bear defensive awareness on the other side. That is the general map of psychosocial relationship between Islamic modernism and traditionalism in many places, including in Indonesia. If in the past, traditionalism is only a practice and custom which was conducted without ideological pretensions except an individual rewards in the form of satisfaction and inner peace, "nuisance and annoyance" of reformist group in fact become a strong reason to assert traditionalist identity into the resistance movement that is ideological, methodological and organizational. ${ }^{9}$ As a result, when the aggression of the reformer continues to expand its influence, Islamic traditionalism silently consolidating itself in a strong line parade.

\section{Indonesia: A Base of Traditionalism}

In the broad area of the Islamic world, the consolidation of Islamic traditionalism first appeared in Indonesia. In contrast to the $18 / 19^{\text {th }}$ century along the Arabian Peninsula, where the tradition evolved as a "practice alone" in line with the rise of schools of Sufism and tariqah movement, traditionalism in Indonesia emerged as a reaction of resistance. This reaction emerged for the first time in the early $20^{\text {th }}$ century through the resistance of the peoples in Sumatra and the establishment of Nahdhatul Ulama in Java. In Sumatra, the movement appeared in Minangkabau between the years 1913-1916 under the influence of Syeikh Ahmad Khatib's modern thought and the widespread of Padri that is anti-tradition. The movement was initiated by the local leader who is hostile to Islam, Datu Sultan Maharadjam, who felt his position threatened. Working with the nobility, he formed the Sarikat Adat Alam Minangkabau that had never experienced significant progress. The second reaction came from the local Muslim traditionalist. Two opposing groups debated the issue several times on Islamic practical issues such as uṣalli, talqīn, ru'yah, karämah, ijtihād and taqlid. Syeikh Mungkar and Syeikh Khatib Ali published several writings that contain a lot of defense on tareeqa that is attacked by the reformers. Facing the attact of the Young (Kaum Muda), the traditionists (Kaum Tua) establish Ittihadul Ulama Minangkabau (Association of Minangkabau Ulama) in Bukittinggi in 1921. Until the 1930s, the resistance movement of traditionist did not develop because the reformist was more powerful in the Minangkabau who later became a fertile ground of the development of Muhammadiyah introduced by Haji Rasul. In Java,

\footnotetext{
${ }^{9}$ The emergence of ideological schools of Ahl al-Sunnah wa al-Jamā'ah (Aswaja) that serves not only as modifiers of the Shi 'ite groups, but also understood and experienced as resistance to the modernist ideology of "incompatible" with Islam of Aswaja. The Aswaja is also a typical worship ideology that must be maintained. NU leaders, KH. Ali Ma'shum, specifically writing a book, Kebenaran Argumen Ahlussunnah Wal Jama'ah (1983). Methodologically in the sense that traditionalism has become distinctive schools of Islamic thought, and organizers are organized through NU tradition with activities programmed social whether related activities associated with religious or purely political moments. For writing that is representing the principles and views of NU, see Abdurrahman Wahid, "Nahdhatul Ulama dan Islam di Indonesia Dewasa Ini," Prisma, April (1984).
} 
the reaction against the reformists appear in Surabaya with the establishment of Muslim clerics organization that is to preserve the Islamic heritage of the past namely Nahdlatul Ulama (NU), established by KH. Hashim Asy'ari and KH. Wahab Hasbullah on January 31, $1926 .{ }^{10}$ In the international context, the establishment of NU is inspired by the idea to defend against the spread of the Wahhabi movement in Saudi Arabia. In Indonesia, Wahhabi's effect has been identified by way of the establishment of Muhammadiyah and Persatuan Islam as "Wahhäbì stooge" that carries the mission of cleaning traditional belief of the people.

It appears that the motivation of both movements was clearly intended as a reaction and resistance to the reform ideology that spread from Saudi Arabia to Indonesia which threaten their existence. ${ }^{11}$ However, Islamic traditionalism itself does not appear in the 20th century. As a reaction to modernism, traditionalism just confirmed its identity at the beginning of the 20th century, but the roots of its own presence had been there long before even before the arrival of European colonialism in Southeast Asia. If modernism emerged related to the influence of modern Western civilization to the world of Islam, traditionalism is the soul and the breath of the presence of Islam itself which has been rooted as a local power in various areas, including Indonesia.

Islamic traditionalism is formed through a long process of Islamization of the Archipelago since its presence up to the 18th century when Islam had spread and become the identity of the majority of Indonesian people. Some elements which are interrelated and proceeded form the distinctive characteristics which then referred to the so-called Islamic traditionalism. First, the color of Islamic mysticism that comes to the Archipelago, especially since the 13th century after the fall of Baghdad by Hulagu Khan of the Mongol troops in 1258. Anthony John is one who hold this theory. Since the fall of Baghdad, the Islamic world has been dominated by the ideology of Sufism and Sufis from the Middle East then spread to various countries like China and Southeast Asia for trade and spread of Islam. ${ }^{12}$ Sufi schools found its common ground with the reality of the mystical Hindu thought of natives so that conversion to Islam is felt not much alter the pattern of their old beliefs. Johns describe them:

\footnotetext{
${ }^{10}$ See Deliar Noer, Gerakan Modern, 235-243.

${ }^{11}$ As noted by Noer, Nahdhatul Ulama was built in Surabaya in 1926 with two main purposes: "First, to counterbalance the Khilafat Committee which gradually fell into the hands of reformer group; second, to propose to Ibn Sa'ūd, the new ruler in Saudi Arabia, so that the religious tradition can be passed." See Noer, Gerakan Modern Islam, 242.

${ }^{12}$ Although approved, Ricklefs still doubt this view arguing "there is no record of any one of the Sufi brotherhoods organized in Indonesia at the beginning of that period" (1993: 18). Ricklefs wonder this is the representation of a group of historians of Southeast Asia that have not been able to find answers to why Islam is widespread and accepted the consolidation of the Archipelago without a strong organization in the modern sense.
} 
They are nomadic teachers who go into different directions across the world they know, they live as it is and dealing with local traders or craftsmen in their own way; they teach theosophy that has been mixed and is widely known by the Indonesian people but what they already believe, even though it is a form of the development of Islamic teachings. They have supernatural powers, the power to heal ... The teachers of Sufism with their abilities and spiritual power are able to attract the hearts of girls and marry the daughters of Indonesian nobility, and thus, their children have influence of king's descendant that strengthen the legitimacy and complement their religious charisma. ${ }^{13}$

Second, the supple and flexible method of cultural Islamization by adopting local values and not using a radical approach. This method is added to facilitates the acceptance of Islam by the natives, also leaving a syncretism which is often regarded as the color of traditionalism. Third, schools of Shafi íyyah as the majority Muslim Southeast Asia which emphasize aspects of the loyalty and respect for religious leaders (kiai, clerical). Fourth, the accommodative nature of Islam is met with the reality of the agrarian mind and indigenous mentality that is still simple and still filled with mystical tendencies due to its close to nature. In evolutionary, the indigenization of Islam for centuries formed the roots of thought that emerges traditionalism.

From the description above, it is clear that to abolish the indigenous Islam is really a difficult job to not say wasting time. Due to its strong root of traditionalism, whatever shouted by modernist group will only be seen as a annoying alien. This is the reason when the modernists group tried to separate tradition from Islam, what they showed is, on the contrary, a counter act in the form of traditional consolidation and identity confirmation. As a result, we see the failure of modernist mission. ${ }^{14}$ Rather than disappear, Islamic traditionalism in Muslim societies strengthens its presence in line with the dizziness and disorientation of modern Western civilization. ${ }^{15}$ Secularization, born from the womb of modernization,

13 A.H. Johns, "Sufism as a Category in Indonesian Literature and History," Journal of Southeast Asian History, 2: 2 (1961): 10-23.

${ }^{14}$ Just in terms of the followers alone, as a measure of the modernist failure to eradicate tradition, the proportion of traditionalist followers are much more than the modernist one. NU claimed its membership of 30 million people, Muhammadiyah has 28 million and Persatuan Islam estimated no more than 4 million. The large number of Muhammadiyah members is not caused by its success to eradicate the tradition, but because of its huge program in the modern sectors, such as schools, universities, hospitals and other social institutions.

${ }^{15} \mathrm{NU}$ large number of followers not only evidence of the consolidation of traditionalism, but it has grown into the largest Islamic organizations that politically and culturally powerful. From the 1955 to the 2009 elections, the NU party has always held the ranks of the largest party. It is from this organization, the fourth president of Indonesia was born, KH. Abdurrahman Wahid. The appointment of Wahid to the presidential office clearly represents the NU stronghold, but Amien Rais made him step down not long after, did not represent as Muhammadiyah but as the Chairman of the People's Deliberate Council (MPR-RI) for violating the constitution of President Wahid. Culturally, Islam Indonesia is a rural base, and rural areas in Indonesia up to now, 74 years 
although not marginalizing and reducing the role of religion in public spaces, on the other hand, has presented spiritual drought that strengthens the important role of religious traditional values.

In addition, the failure of modernism is a matter of wrong perspective. Different perspective is oftenly used to measure whether a religious phenomenon is Islamic or not. The perspective of normative Islam is used to measure historical Islam, orthodoxy is used to measure heterodoxy, Islamic sharia to Islamic culture and the like. Errors of this way of thought is found clearly, for instance, by Marshall G.S. Hodgson, a famous historian with his magnum opus The Venture of Islam (1974) when he criticized Geertz's trichotomy in The Religion of Java (1960). Hodgson said Geertz's work as brilliant but unfortunately marred by "a major systematic error." 16 This is because Geertz's analysis, according to Hodgson, is influenced by the modernist idea that is sharia-minded. Geertz identifies 'Islam' only based in what is found in modernist circles so he describes many of Javanese traditions (especially abangan) as an Aboriginal heritage or Hindu-Buddhist. Recklessly, said Hodgson, Geertz gave labels to many Javanese Muslim religious life as 'Hindu.' Local traditions which are considered as Hindu is actually Islamic universal phenomena, and even sometimes found essentially in the Quran, but Geertz calls as "un-Islamic." Thus, for Hodgson, Geertz's interpretation of Islam of the past, as demonstrated by the reactions of anti-Islam today, is "highly misleading." Geertz's mistakes, according to Hodgson, are found in three roots of problem:

When he refers to the Archipelago having long been cut off from 'the centres of orthodoxy at Mecca and Cairo', the irrelevant inclusion of Cairo betrays a modern sources of Geertz's bias. We must suspect also the urge of many 'colonialists to minimize their subjects' ties with a disturbingly world-wide Islam (a tendency found also among French colonialists in the Maghrib); and finally his anthropological techniques of investigation, looking to a functional analysis of a culture in momentary cross-section without serious regards to the historical dimension. Other writers have recognized better the Islamic character even or inner-Javanese religion: C.A.O. van Nieuwenhuije, Aspects of Islam in PostColonial Indonesia (The Hague, 1958); W.F. Wertheim, Indonesia Society in Transition ( $2^{\text {nd }}$ ed., The Hague, 1950), but Geertz stands

after the founding of NU, remains the basis of traditional Islam. Traditional religious practices since the beginning of the 20th century which have been regarded as heresy and superstition are never disappeared, even emerged the new practicers of urban communities. Groups of Sufism studies and thariqah followers, rather than reduced even more fertile in urban areas in Indonesia since the early 1980s. Moeflich Hasbullah, "Cultural Presentation on the Muslim Middle Class in Contemporary Indonesia," Studia Islamika: Indonesian Journal for Islamic Studies, 7: 2 (2000): 1-58.

${ }^{16}$ Marshall G.S. Hodgson, The Venture of Islam: Conscience and History in A World Civilization, Vol. 2 (Chicago: The University of Chicago Press, 1985), 551. 
out in the field. For one who knows Islam, his comprehensive data dispite his intention- show how very little has survived from the Hindu past even in inner Java and raise the question why the triumph of Islam was so complete. ${ }^{17}$

However, although the Islamic traditionalism has confirmed its identity and existence through organizational and cultural programs like what has been developed by NU, it should be admitted that modernist mission does not mean totally fail. Underpinned by the modernization, rationalization and secularization process, the modernist effort to eradicate the tradition in Islamic society, at a certain level, gains its results signed by the tendency of weakening cohesiveness of the Muslim community to the practices of religious traditions that strongly united in social life in the 1980s. ${ }^{18}$ However, it is not without risks. Islamic modernism might be proud with the disappearance of religious tradition but, unconsciously, Muslim society has lost their valuable cultural assets that have effectively united them with the spirit and religious nuances. Rahmat ${ }^{19}$ recorded five disadvantages suffered by Muslims due to the erosion of tradition in the Islamic society made by modernist movement: "depribumisasi" (deindigenousation), "demistifikasi" (demystification), "degaibisasi" (despiritualisation), "deinstitusionalisasi" (deinstitutionalisation), and "disintegrasi" (disintegration).

Depribumisasi is the process of tradition detachment that has been united and rooted in the socio-cultural life. Many Indonesian ethnicities which have been rooted and culturally identical with Islam such as Aceh, Malay, Minangkabau, Bugis, Banjar and Sunda. But, Jalal remarks, the

\footnotetext{
${ }^{17}$ Hodgson, The Venture of Islam, 551. Hodgson is just one of the critics of Geertz, from other domestic and foreign scholars scattered. See, among others, Robert R. Jay, Santri and Abangan: Religious Schism in Rural Central Java (1957); Koentjaraningrat, "Pembicaraan Buku Clifford Geertz, The Religion of Java," Madjalah Ilmu-ilmu Sastra Indonesia, 1: 2 (September 1963): 188-191; Harsja W. Bachtiar, "The Religion of Java: A Commentary," Indonesian Journal of Cultural Studies, 1: 5 (January 1973): 85-114, etc. On the comparative study of Islam and Hindu Javanese, see Robert W. Hefner, Hindu Javanese: Tengger Tradition and Islam (Princeton: Princeton University Press, 1985). Indonesian scholars considered Geertz does not really understand the structure of the Javanese community because of his mistake in making categorization abangan-studentsgentry in the social stratification of the Javanese community.

${ }^{18}$ Although the roots of the tradition is not lost, but it must be acknowledged that compared to the 1980 back, today's modern Muslim community's commitment to run the Islamic tradition is much reduced. Muludan activities commemorating the birth of the Prophet have been defeated by the vividly secular muludan activities such as birthdays of organizations, companies or individuals. Implementation of the Isrā' Mi 'räj is also reduced and less crowded by the celebration of Indonesian Independence day (August 17) of nation. Traditional festival atmosphere during Ramadan is reduced, marhabaan increasingly hard to find, loyalty and respect for the 'ulamā weakened (fatwăs are often not respected), the public interest, especially children in the faint șalawatan as homage to the Prophet's tradition to change into the interest in singing secular bands and looking for stars. Idol to the Prophet changed into an idol to the artists and celebrities. Celebrating1 Muharam (Islamic New Year) far less by the excitement of the new year of January 1. Nazaman in mosques is recited before five-time prayers that bring religious nuance, reminding temporality of worldy life is more rarely heard and so on. All the mentioned above remain only in certain rural areas, traditional pesantrens and mosques. See Rakhmat's further explanation of the Muslim disadvantages due to loss of this tradition in his Islam Aktual: Refleksi Sosial Seorang Cendekiawan Muslim (Bandung: Mizan, 1991), 118-126.

${ }^{19}$ Rakhmat, Islam Aktual, 118-126.
} 
modernists came with their puritanism and called it as "syncretism." This is the process of deindigenousation.

Local religious elements are claimed as bid'ah (unIslamic) just because they found no authenticity in the Quran and hadith... the modernists seceding from native roots. Islam becomes something strange and Muslim modernist alienated from their community. That is why, perhaps, politically, Islamic ideology is not widely accepted... Islamic alienation of the local culture has prompted nationalists to seize 'Muslim land.' Because the modernists left their grassroots, the communists then occupied it. [Meanwhile] the Christians have continually been striving to integrate Christian teachings into the local culture. They built local churches (note the case of Kiai Shadrach, HKBP, Pasundan Church and so on) ... the movement of modernists' depribumisasi has been fatal, especially in dealing with Christian indigenousation. ${ }^{20}$

Demistifikasi is the process of elimination of the role of sufism in public life. While sufism and mystical trends have been instrumental in expediting the Islamization in Indonesia because they have common ground with Hinduism and Buddhism, which was unimaginable if Islam came as Wahhābi, "the modernists came to the point of sufism as a cause of weakness of the Muslims. All matters relating to sufism was hit. Then come up the demystification call, which consequently felt to this day. As the antithesis of Sufis who seek meaning and 'secrets' of Shari'ah, the modernist formalism turn ... Islamic teachings into fiqh-centric. Nash is only superficially understood ... What is important is sunnah-innovation dichotomy, halal-haram, tawhid, shirk, Islam-ignorant. The process of inner purification, increasing moral and spiritual exercises are no longer worthy of attention. Modernists more attention to how to straighten the hand when performing shalat than straighten out when ... When the modernist worship rid of mysticism, they get rid of the emotional religious experience, religion enjoyed a rational ... Modernists deny the religious mystical dimension. Many of them fled to the local mysticism. Cult to grow lush, fill the vacuum left by the modernists. ${ }^{21}$

Degaibisasi is a process of downsizing efforts of the unseen things in life. "Along with the depletion of the inner aspects of religious life, the things unseen diminished role. Although the Quran explicitly states that features of the righteous 'yu'minuna bi al-ghayb,' the modernist rationalism-with-magic underestimated. It is often the texts that tell supernatural events wrongly perceived to be completely "reasonable." AlManār, the modernist Quranic exegesis, often tries to rationalize the

\footnotetext{
${ }^{20}$ Rakhmat, Islam Aktual, 121.

${ }^{21}$ Rakhmat, Islam Aktual, 122-123.
} 
supernatural events in the Quran ... Once the spirit of al-Manār to deny the supernatural angels are only considered as quwwah tabi íiyyah (natural forces) only. Satan was just a force of nature. Al-Manār was followed by alMarāghi, also references the modernists. Degaibisasi process produces a materialistic conceptualization of tawhid. Recognized only material causes in the physical world ... supernatural causes eliminated. When you treat abdominal pain with Entrostop, you follow the causes of birth. Your treatment in ways that justified Islam. If you treat it with al-Fätihah, you are a paganist. In this context, the modernists blame people who do perform tawașul and tabarruk ... The students who sipped the water kiai, pilgrims who rubbed cemetery trustee, a congregation that kissing the pulpit of the Prophet in Medina, the people of Indonesia who drink Zamzam water to cure the disease. Modernists accuse it of all acts of shirk. As a result, anything involving the supernatural are considered shirk, including studying the occult forces through hizib and riyadah. One of the pillars of religion is belief in the supernatural. Weaken the faith of course impoverishes religion experience. $^{22}$

Next is deinstitusionalisasi, namely the process of weakening religious understanding that has already been institutionalized. "The belief in the supernatural often strengthens Islamic institutions. One of the institutions is 'ulamā. Tabarruk to the living "ulamā strengthens their role in leading the umma. Tabarruk to scholars who have passed the line connecting the history of the passing of time and space. Scholars are not merely temporal models; scholars also directions for sacred things. Conversations have the authority, breaking them will cause disaster. With such credibility, communication scholars to be highly effective ... Scholars to be the leader of the polymorphic-led walks of life. Come clear dogmatic modernists. All persons, including those not qualified - should diligence. Referenced rather than scholars, but the Quran and the hadith ... It is not uncommon understanding of the science was done without adequate provision. Scholars demolished institutions, and the emerged amateur mufassir or mujtahid. 'Ulamā slowly eliminated. At first from the pulpit preaching, over time, as well as from the pulpits of Friday ... In line with deinstitusionalisasi scholars, Islamic values socialization goes without direction ... the most hectic opinion issued by the layman, confusing people. From this fact the cause of the birth of splinter groups. ${ }^{23}$

Last is the disintegration. Disintegration is the process of people's conflict each other for abandoning a tradition that has been fused with their lives. Traditionalism has an adhesive function of social ties, integrate and strengthen the cohesiveness of society. When the adhesive and cohesive element is abandoned, the bonds of the people then are in a loose, easily

\footnotetext{
${ }^{22}$ Rakhmat, Islam Aktual, 123-124.

${ }^{23}$ Rakhmat, Islam Aktual, 125.
} 
broken and lost its cohesiveness because they loss the traditional figures of religious leadership that is able to integrate the community. "Splinter group born out of an organization which is generally the role of 'ulama are not so strong. The new figures are born, try to give answers to actual problems. With less knowledge, they gave simplistic answers. They also gathered around the congregation who is also a simple thought. There was fragmentation of the people, into small pieces. Among scholars there are also differences of opinion. But the impact of these differences can be minimized, because scholars have standard conventions to resolve ... differences of opinion among the early difficult to overcome. They do not have these conventions. Finally, differences of opinion ... The modernist divisions bear to admit that the prohibition of taqlid was dysfunctional. In the institution there was taqlid that integrates the power of the people. Victory of the ulama in Iran show how the taqlid has strengthen the role of 'ulama institution. Power of ulama, socially and financially, had been penetrated by the temporal power." 24

\section{CONCLUSION}

From the above discussion, it appears that Islamic tradition that has rooted in Indonesia for centuries has been a larger movement than Islamic modernism itself. This is caused by several things. First, insincerity of Islamic modernism. When it was organized or grouped as a movement, modernism is no longer an idea, rather than sincere appeal to the progress and modernization, it turned into a vested interest group. Once it happened, this will be seen and felt by the traditional wing as no longer a genuine movement for the advancement of thought, but seen as disturbance and annoyance of a "new religion." Second, differences in the understanding of religious perspectives and the measures taken to make the thought had never met. Both sides end up together to defend themselves, to walk on their own and it is difficult to reconcile the unity of views, especially when this unification effort is tainted by ulterior motof organization's interests, fight the influence of the positional and practical political orientation. Third, eradication and elimination efforts only keep the tradition of a sense of religious community rooted in indigenous values that would have been the nature and strength of Indonesian Islam, Islam away from the shady and cool, creating understanding and religious behavior and nourish dry and stiff spiritual aridity. Fourth, as described by Jalal, the loss of tradition is sociologically much harmfull to Islam itself. Fifth, the fact that Islamic traditionalism would be more powerful and become deep-rooted culture, traditions of thought and richer and enlightened intellectuals, the organization and more adherents, and the fact that traditionalism is more

${ }^{24}$ Rakhmat, Islam Aktual, 126. 
alive and gives the place and the answer to the religious orientation of human modern. Above all, it seems reasonable to recommend that efforts to "modernize" Islam Indonesia in the sense described above been losing momentum. Propagation of modernization is no longer something that is' significant needs of the people. Instead, it's time to look for the Muslims of Indonesia more than difference equations.

Indonesian Islamic challenges are no longer traditionalism, no longer the variety of Islamic understanding and thought, no longer group differences. The more challenges are poverty, educational backwardness, destruction of nation's moral characters that presented by the political elites of this country especially by the phenomenon of corruption that has become the nation's mentality in almost every social layers. Even more in comprehensive look, we can emphasize that the common enemy is not really religious fundamentalism, terrorism and even poverty. The most obvious one is mass culture which has been producing taste, flavor and low consciousness of the human, such as the materialist and hedonist behaviors, which has surrounded and twisted people from various sides that are promoted by capitalism, which then become a source of moral damage and destruction of social consciousness of modern man.[]

\section{REFERENCES}

Abdullah, Taufik, ed. Sejarah dan Masyarakat. Lintasan Historis Islam di Indonesia. Jakarta: Pustaka Firdaus, 1987.

Ali, Fachry and Bahtiar Effendy. Merambah Jalan Baru Islam: Rekonstruksi Pemikiran Islam Indonesia Masa Orde Baru. Bandung: Mizan, 1986.

Azra, Azyumardi. Jaringan Global dan Lokal Islam Nusantara. Bandung: Mizan, 2002.

Bachtiar, Harsja W. "The Religion of Java: A Commentary," Indonesian Journal of Cultural Studies, 1: 5 (January 1973): 85-114.

Bruinessen, Martin van. "Mencari Ilmu dan Pahala di Tanah Suci: Orang Nusantara Naik Haji," Ulumul Qur'an, 2: 5 (1990): $42-49$.

Burhanuddin, Jajat. "The Fragmentation of Religious Authority: Islamic Print Media in Early $20^{\text {th }}$ Century Indonesia," Studia Islamika: Indonesian Journal for Islamic Studies, 11: 1 (2004).

Hasbullah, Moeflich. "Cultural Presentation on the Muslim Middle Class in Contemporary Indonesia," Studia Islamika: Indonesian Journal for Islamic Studies, 7: 2 (2000).

-------. "Korupsi sebagai Kelemahan Jiwa," Republika, 12 July 2010.

Hefner, Robert W. Hindu Javanese: Tengger Tradition and Islam. Princeton: Princeton University Press, 1989. 
Hodgson, Marshall G.S. The Venture of Islam. Conscience and History in A World Civilization, Vol. 2. Chicago: The University of Chicago Press, 1985.

Jay, Robert R. Santri and Abangan. Religious Schism in Rural Central Java. Cambridge: Harvard University Press, 1957.

Latif, Yudi. Masa Lalu yang Membunuh Masa Depan. Krisis Agama, Pengetahuan dan Kekuasaan dalam Kebudayaan Teknokratis. Bandung: Mizan, 1999.

Koentjaraningrat. "Pembicaraan Buku Clifford Geertz, The Religion of Java," Madjalah Ilmu-ilmu Sastra Indonesia, 1: 2 (1963): 188-191.

Ma'shum, K.H. Ali. Kebenaran Argumentasi Alussunnah Wal Jama'ah. Pekalongan: Udin Putra, 1983.

Nasution, Harun. Pembaruan dalam Islam, Sejarah Pemikiran dan Gerakan. Jakarta: Bulan Bintang, 1992.

Noer, Deliar. Gerakan Modern Islam 1900-1042. Jakarta: LP3ES, 1985.

Peskes, Ester and C. Holes. "Wahhābiyya," The Encyclopedia of Islam, ed. P. J. Bearman, Th. Bianquis, C. E. Bosworth, E. van Donzel and W. P. Heinrichs. Leiden: Brill, 2002, 11: 39-47.

Rakhmat, Jalaluddin. Islam Aktual. Refleksi Sosial Seorang Cendikiawan Muslim. Bandung: Mizan, 1991.

Ricklefs, M.C. Sejarah Indonesia Modern. Yogyakarta: Gadjah Mada University Press, 1993.

Steenbrink, Karel A. Beberapa Aspek tentang Islam di Indonesia Abad Ke19. Jakarta: Bulan Bintang Jakarta, 1984.

Wahid, Abdurrahman. "Nahdhatul Ulama dan Islam di Indonesia Dewasa ini," Prisma, April (1984). 